\title{
The Impact of Virtual Technology on Teachers Candidates' Self-efficacy: A Literature Review
}

\author{
Sadia Bibi \\ $\mathrm{Ph}$ D Student \\ Department of Education, IUB \\ dia.g4424@yahoo.com
}

\author{
Dr. Abid Shahzad \\ Assistant Professor \\ Department of Education, IUB
}

Malik Adeel

LLB, The Islamia University of Bahawalpur

\begin{abstract}
This study evaluated the impact of virtual technology on teacher candidates' self-efficacy. Teacher self-efficacy based on empirical validity in face-to-face environments remains continuously, while it is a new concept in an online education environment. The following literature review conducted among different academic electronic databases and examined the 15 years passed published work. The literature review explores three major areas of research in online education about technology on teacher candidates' self-efficacy. (1) self-efficacy of pre-service teachers by adopting virtual technology (2) association between teaching self-efficacy and virtual technology (3) changes in self-efficacy of a teacher before and after a professional development with the help of virtual technology. The study described that different researchers continuously examine the balance between pedagogical and technological knowledge that supports the professional development of pre-service teacher self- efficacy with the help of virtual technology, whether teacher self-efficacy differs in online education as compared to face-to-face education.
\end{abstract}

Key Words: Online Education, Online Learning, Virtual Technology, Teacher Education; Selfefficacy; Pre-service Teachers.

\section{Introduction}

Education is a preamble role in the development of youth, communities, and countries. While all over the world different societies try to enhance the quality of education for their youth and children. It has also become crucial to pay attention to improve the quality of education for future teachers. Different research shows that teacher education programs are currently faced with at least two major issues (Girod \& Girod, 2006).On one hand is the number and complexity of responsibilities and skills required in teacher education program have significantly increased day by day and teachers nowadays are expected to be highly versatile, alert and "skillful in aligning, contextualizing, selecting, adapting, analyzing, explaining, and instructing the important content, 
while working within administrative systems that typically do not support cooperation, planning, consideration or professional growth" (Girod \& Girod, 2006). On the other hand, today competition is highly increased for available teaching jobs. It is necessary for teacher candidates to demonstrate their teaching skills for enhancing students learning(Kaufman \& Ireland, 2015).

The ability to measure a person's capabilities in the particular context of teaching is called teacher self-efficacy. Bandura the psychology scholar was used the term 'self-efficacy' first time (Bandura, 1997). Bandura defined self- efficacy of a Teacher as workable and indicate its alliance to students outcomes (Bandura, 1997; Goddard et al., 2017). The appealing concept is a Selfefficacy for the teachers as it strongly relays on the component that is often under teacher control.

The foundations that are empirically approved mostly based on Bandra's social cognitive theory, the area of human psychology that has been a theme to sizeable verifiable scrutiny over the years and has remained relatively intact. The teacher self-efficacy construct offers the different useful opportunity for research in the context of online education it looks logical to propose as compared to face-to-face learning that affecting student outcomes (Bandura, 1993). The findings of this literature review provide the opportunity for new research in this area and support this proposition. To improve teacher self-efficacy level in online-based learning additional education programs and research design is developed. For improving student success additional resources and time is also allocated. In the pre-service teacher's education program the extensive practice is required in managing classroom behavior and delivering quality instruction for all students in the actual classroom.

According to Boiselle to prepare teacher educators for future diversity and complexity of the classroom field experience practice is more important. However, teacher educators in the actual classroom environment face different challenges for pre-service teachers where their students will receive the routine learning and complete their tasks (Boiselle, 2012). Traditional face to face education programs for pre-service teachers provides different experiences to allow teacher candidates in behavior management and develop teaching skills as compared to online education. All these experiences included observation of student teaching practicum- learning and actual field experience included as a component are critical in comprehensive teacher education programs (Vita \& Graham, 2017). 
Although in face-to-face education environments teacher self-efficacy empirical validation continues, in the online education system it counts as a new concept. The suggestion by different researchers is that the difference between face-to-face classroom environment and online classroom environment is reflective enough to compare teaching and learning qualities and characteristics (Rice, 2003). The self-efficacy of a teacher is used to measure a teacher's opinions that may be affected on student achievements. Students learning and growth in traditional facetoface classroom environments having a high degree of correlation with teacher selfefficacy(Goddard, Skrla, \& Salloum, 2017).Student's successful outcomes are strongly effected on the educational system. Teacher self-efficacy increase interest for both teachers and researchers.

A framework based on the theory presented by Bandura to explain the effect of psychological procedures on a person such as therapy. Bandura proposed that by alternating the level of self-efficacy its effect on an individual in a psychological way should be measured. According to Bandura's theoretical framework, the expectation of efficacy is the technique in which changes in self-efficacy can easily find out, also the expectation of efficacy influences student outcomes. Bandura designed a paper of self-efficacy, where an individual was integrated with self-efficacy (Bandura, 1997).Teachers are expected that they have the ability that affects student outcomes which are called teacher's self-efficacy(Armor et al., 1976).

In 1970 the RAND studies firstly measure self-efficacy of teacher and based on Rotter work (Armor et al., 1976; Tschannen-Moran\& Hoy, 1998). RAND is a global organization which is studies student outcomes and public policy worldwide. Rotter (1981)presented a hypothesis about the required relationship between individual efficacious behavior and their outcomes. A research study by RAND organization was conducted for factors identification that led student reading outcomes toward success. The main factor which was identify is teacher efficacy. Selfefficacy construct by Bandura's in 1977 became more known, a significant difference noted by different researchers between the Bandura theories (efficacy expectation based) and Rotter theories (efficacious behavior-based) and a difference in how to measure efficacy (Dellinger, 2005; Tschannen-Moran et al., 1998).

R.McCrae said that "unspoiled the link between course task to actual classroom practice offers the opportunity to pre-service teachers to integrate teaching skills and pedagogy for 
becoming a required good teacher (R.McCrae, n.d.). Today, there are a number of scales used in teacher efficacy measurement and teacher self-efficacy measurement scales. Few instruments may be not accounted sufficiently for measuring differences in the theories. Therefore, we must keep in mind that instrument statements can make an insightful impact on the results interpretation.

Virtual reality (VR) is basically a simulation-based experience that can have similarity or otherwise of the real world. Virtual reality is often based on infotainment, education, learning, gamification, and simschooling, military or medical simulation and trainings (Theelen, van den Beemt, \& den Brok, 2019). The current practices of virtual reality are based upon using the headsets, sound systems, videos to create a real-life environment while simulating the users' physical presence in a virtual scenario (Caspersen, 2015). Learning management system (LMS) is considered one of the impressive and time managing softwear that deals with web-based planning and implementaion of learning material, teaching mechanism and operational strategies of transformation of material. In the current COVID-19 senarion- under the directions of Higher Education Commission of Pakistan- LMS has been implemented by the major universities in Pakistan to manage the online teaching effectively.

According to different researchers the virtual education environment and face-to-face education environment is different from each other, therefore deserve different examination, and especially. After all in self- efficacy measurement the virtual context is a center in online education. According to Bandura, one individual cannot be mastery of all things in the realm of human life. People's efficacy area is differing from each other in their work levels within given situations. For example, businessman may be a very high organizational efficacy level as compared to parenting efficacy. Efficacy belief is a combination of a different set of self-beliefs. In accumulation according to context task specificity and environment are also at the heart of meaningful teacher self-efficacy measurement (Bandura, 1997; Dellinger, 2005; TschannenMoran et al., 1998).

Different instruments have been used to measure teacher self-efficacy in online education. All instruments are internally validated scales that used in traditional face-to-face teacher education system. The instruments used for teacher self efficacy measurement have not mentioned about the use of education technology use (Hu et al., 2019; Limbong, 2017). Instead, the measuring instrument scales were designed to measure content-specific pedagogy or general content pedagogy. In the given context, different research suggests a connection between teacher 
selfefficacy and technology use in the classroom (Koehler \& Mishra, 2006; Mccrae, 2010; Watson, 2006)

Research that links together teacher self-efficacy and technology integration in online education may be especially important, where technology use is at the heart of learning and teaching. Few efforts have been done on teacher self-efficacy instrument to especially modify and internally validate for online education, but as compared to online education the special efforts has been observed in a traditional face-to-face environment. The purpose of this literature review article is to measure the methods of teacher self-efficacy measurement in online education.

\subsection{Virtual Technologies Used as Experiential Learning in Teacher Education}

The pre-service teachers' education programs used different virtual technologies for ameliorating issues previously described. The technology could provide a broader exposure to preservice teachers for various styles of learning and teaching situations. There are so many types of benefits to using technology in the pre-service teachers program. The pre-service teachers can be better prepared by the use of different technology because teachers can practice pre-planned specific skills in actual fully controlled teaching and learning environment (Theelen, van den Beemt, \& den Brok, 2019).

On the other hand, pre-service teachers can repeat and exercise various scenarios and tasks with varied outcomes. There are many types of virtual technologies that exist for teacher preparation. A study conducted by Caspersen (2015) review of how technology has been used for pre-service teacher preparation programs.

The field experiences enhanced and developed by the help of technology can be divided into three major categories of concreteness, arranged according to scales from real life to virtual environment. The first actual field experiences include concrete and direct experiences in the classroom as compared to traditional face to face education system approaches in which preservice teachers are experienced in real classrooms. Technology in the online education system is used to facilitate communication, reflection on the task, and supervision duty. At the second experience, pre-service teachers remotely observe students with the help of different video cases or by videoconferencing. From all aspects, the field experiences are based on technology, such as computer-enhanced simulations and virtual reality. Technology plays an important role in the first two field experiences. However, for the third type of field experience on the simulated and virtual 
environment is very few. The purpose of this review article was to identify quantitative, qualitative, and mixed studies that used different technology in pre-service teacher's training.

\subsection{Objective of Research}

In this review article three major areas were identified:-

1. To measure the self-efficacy of pre-service teachers by adopting virtual technology in teacher training education program.

2. To measure the association between teaching self-efficacy and virtual technology in teacher training.

3. To measure the changes self-efficacy of a teacher before and after a professional development by virtual technology.

\section{Methodology}

The articles used in this review of the literature were based on a systematic search of electronic databases such as JSTOR digital library, Education Research Complete, Education Full Text, Educational Resources Information Clearing House (ERIC), Psychology and Behavioral Sciences Collection and Psych INFO that all databases are for education category. For searching material a criteria were developed to chose different articles for online education to minimize the non-standardized classification in the research (Corry, Ianacone, \& Stella, 2014). According to the selected search criteria, the first was online education, learning online, virtual learning, virtual school, Cyber School, teacher education, pre-service teachers, and virtual technology. The last criteria were self-efficacy. To reflect on online education and the dynamic nature of technology an additional search criterion was added, the research articles were published before 15 years were not included in this article. The resulting article's title and abstract were reviewed, to identify the seemingly matched studies to the selected criteria for including in this review of the literature. These search parameters showed 441 articles.

The next step is omitted the search resulting duplicate articles by the help different of multiple databases and close read the remaining articles abstracts. As a result, 13 articles matched all including search criteria. The matched 13 articles bibliography was further searched for supplementary articles that might be accurate to include in the study. It was noted that measuring the teacher self -efficacy the Technological Pedagogical and Content Knowledge framework (TPCK or TPACK) and the Technology Acceptance Model (TAM) were frequently used(Davis, 
1989; Koehler \& Mishra, 2006).Additional keywords were added to search about 'TAM', 'TPCK', and 'TPACK'. The research studies classify by area OR theme document analysis was undertaken. In this literature review, all the discussed data were collected by interview and survey(Hart, 1998).

\subsection{Adopting Online Teaching}

Different researches were undertaken to find out whether teachers might adopt online teaching easily which affects their self-efficacy. To predict technology integration and its usage in the business environment, the TAM model was presented by (Davis, 1989). The TAM model is taken from behavioral decision theory(De Sousa \& Yu, 2014), self-efficacy theory (Bandura, 1997), and the Channel Disposition Model (Corry \& Stella, 2018). According to Davis TAM model was originated by identifying that technology has the power to change organization performance, but people often refuse to adopt the technology. If organizations could offer training and/or counseling before implementing a particular technology they can achieve better results (Davis, 1989).

As a survey instrument, the TAM model is used. It perceived ease and usefulness of technology use. To observe teacher behavior in the online education system the TAM model is often used. The 3-TUM model, derived from the TAM model, was used in the study (Chou, 2014)to measure the association between teacher self-efficacy and the intention to use e-learning. The language of human agency is used by TAM. To observe teacher behavior often use TAM model in the online education system. The TAM model, in the study was used to measure the link between intention to use e-learning and teacher self-efficacy (Chou, 2014).30 teachers overall participated in the study.

The finding shows that satisfaction about technology uses influenced teacher self- efficacy levels. While on the other hand self-efficacy play a role of predictor for teachers to use technology at the actual classroom. One research study of 152 in-service teachers refuse the TAM model and the results show that the predictor for e-learning was the ease of use, but not e-learning usefulness (Amer, Ahmad, \& Jo, 2013). The student academic outcomes were not measured in any study and explicitly self-efficacy as a construct was not defined in the reports. However, teacher behavioral intention understanding may generalize across primary/secondary and higher education teachers because they did not examine students but teachers. In many of the research studies, the impact of technical support and systems of technology on teacher self-efficacy has been measured. As such, 
administrators must ensure usable technical support and adequate quality/testing of systems, when the traditional system is converted to teacher's online education.

The TAM model is used to measures teacher self-efficacy, a study was conducted by Corry and Stella on professional development for primary/secondary online teachers and their regulation in the online classroom environment(Corry \& Stella, 2018). The different researchers used a survey that used instructional self-efficacy, instructional practice, technology self-efficacy, and Professional development. The findings showed a logical correlation between instructional selfefficacy and content-related instruction practices. Also teachers show desires for more technological professional development about transmitting their courses from face-to-face education to online teaching.

\subsection{Changes in Self-efficacy}

To measure changes in teacher self-efficacy before and after virtual technology use in teacher education various instruments have been used. The findings show that online professional development and pre-service teacher education programs (or particular focused on technology) play a major role in teacher self- efficacy development (Malik, Rohendi, \& Widiaty, 2019). In online education, the TPACK model is used to find out those teachers who are already linked with e-learning education (online teachers education) and to develop different methods for increasing the TPACK of teachers because to prepare them to teach in a technology-based environment. The study conducted in 2009 among 596 primary/secondary online teachers by the use of the TPACK model for measuring teacher self-efficacy in pedagogy and content. Teachers are not sure about their ability to solve issues of the instrument with students and engage learners with content by the help of different techniques. However correlations of the TPACK components exceptionally high and exceptionally low suggested that further research would be required to measure whether the TPACK model will be useful in online education (Crippen \& Archambault, 2009).

The same data used in another study for further results measurements. The data factor analysis outcomes suggested that TPACK seven domains were not discernible in online education (Pulham, Graham, \& Short, 2018). The correlation is very low among the technology-based components of the TPACK. The recommendations for pre-service teacher education were following. The TPACK model specifically to blended and online environments should be at the center of technical considerations (technology that facilitates student learning), online pedagogy 
differences (when teacher adapted curriculum to an online environment, the implemented teaching strategies is different for fostering student interaction and their assessment), and principles of instructional design (Crippen \& Archambault, 2009).

A study conducted among pre-service teachers noted a difficulty in TPACK domains (Crippen \& Archambault, 2009). The TPACK-based educational technology course completed by pre-service teachers before and after a course the results were compared. Different researchers said that technology integrated instruction about content and methodological maximize teacher selfefficacy level. Few studies suggested that lack of content knowledge slowed down the selfefficacy of pre-service teachers in TPACK development (Özgen \& Narlı, 2020).

Successful online teacher certificate based on the TPACK program not reflect perfectly integration of the content with technology challenges. However at the master level program (MA) where may be content and pedagogical self-efficacy have been developed in advance(Schmidt, Thompson, Koehler, \& Shin, 2014). It is clearly stated that TPACK is a prominent contribution in online education to evaluate teacher education programs and measuring self-efficacy. However, measuring the validity of TPACK in online education more research is needed. The included research studies in this review explained how to measure teacher self-efficacy in online education and association among teaching self-efficacy and virtual technology and teacher self-efficacy used as an evaluative tool to measure online teacher programs. In online education different questions about student success and teacher self-efficacy, unsolved but findings converge on areas of agreement among different researchers.

\section{Discussion}

The impact of virtual technology on teacher candidates self efficacy has been identified three major areas in this review article:-

1. To measure the self-efficacy of pre-service teachers by adopting virtual technology in teacher training education program.

2. To measure the association between teaching self-efficacy and virtual technology in teacher training.

3. To measure the changes self-efficacy of a teacher before and after a professional development by virtual technology. 
Research results show that in online pedagogy measuring self-efficacy has been not defined and validated clearly. A standardized Quality Matters system used in curriculum evaluation is a framework used for continuous evaluation of the online curriculum. In online pedagogy to measure self-efficacy was not validated and clearly defined. Literature shows different results about teacher adopting of online education. A study pointed out the teachers who want to transfer face-to face to online teaching required more professional development to integrate the content with technology and online instruction design (Zyda, 2005).

Research suggest that the way to teach a subject, pedagogy of teaching, technology, teaching content, and others has a strong effect on self-efficacy development in online teacher education (Durdu \& Dag, 2017); as such, it may be beneficial to examine the entire teaching programs instead of focusing on individual courses. Finally, many researchers have noted the difference in the construct of self-efficacy while few researchers have used the terms interchangeably 'efficacy of teacher' and 'teacher self-efficacy'. Efficacy of teacher differs from teacher self-efficacy however it is found that teacher efficacy affects on student outcomes.

\section{Conclusion}

The pre-service teacher's goal is to develop outcomes that are beneficial for students and remain the same, while online education continues to grow at primary/secondary and higher education. This review included different themes identified in the literature, such as the quality in the online education curriculum and technology. More research is needed in specifying and defining the self-efficacy construct in the online education system. It also stated that there are different unanswered questions about to quality in the programs of teacher education and need to further examine the relationship between student outcomes and self- efficacy of the teacher. To explore the association between teacher self-efficacy and student outcomes in the online system of education may bring new knowledge in the teaching field. Also professional development courses and teacher education programs designer may benefit from research that explores an association among content curriculum, teaching technology, and teaching pedagogy in online education.

\section{References}

Amer, A.-A., Ahmad, A.-A., \& Jo, S. (2013). Exploring Students Acceptance of E-learning Using Technology Acceptance Model in Jordanian Universities. International Journal of Education 
and Development Using Information and Communication Technology, 9(2), 4-18. Retrieved from http://ijedict.dec.uwi.edu/viewarticle.php?id=1617

Armor, D. J., Conry-Oseguera, P., Cox, M., King, N., McDonnell, L., Pascal, A., ... Zellman, G. (1976). Analysis of the School Preferred Reading Program in Selected (pp. 1-84). pp. 1-84. Retrieved from http://www.rand.org/pubs/reports/R2007.html

Bandura, A. (1993). Perceived self-efficacy in cognitive development and functioning (pp. 117148). pp. 117-148. Lawarence Erlbaum Associates, Inc.

Bandura, A. (1997). Self-efficacy. Harvard Mental Health Letter, 13(9), 4. https://doi.org/Article

Boiselle, P. M. (2012). Quality matters. Journal of Thoracic Imaging, 27(3), 137. https://doi.org/10.1097/RTI.0b013e31824f4f83

Caspersen, J. (2015). Teachers' Learning Activities in the Workplace: How Does Teacher Education. (January), 46-63.

Chou, T.-C. R. (2014). A Scale of University Students' Attitudes toward e-Learning on the Moodle System. International Journal of Online Pedagogy and Course Design, 4(3), 49-65. https://doi.org/10.4018/ijopcd.2014070104

Corry, M., Ianacone, R., \& Stella, J. (2014). Understanding online teacher best practices: A thematic analysis to improve learning. E-Learning and Digital Media, 11(6), 593-607. https://doi.org/10.2304/elea.2014.11.6.593

Corry, M., \& Stella, J. (2018). Teacher self-efficacy in online education: A review of the literature. Research in Learning Technology, 26(1063519), 1-12. https://doi.org/10.25304/rlt.v26.2047

Crippen, K., \& Archambault, L. (2009). Exmining TPACK among K-12 online distance educators in the United States. Contemporary Issues in Technology and Teacher Education, 9(January 2009), 71-88. Retrieved from http://www.citejournal.org/vol9/iss1/general/article2.cfm

Davis, F. D. (1989). Perceived usefulness, perceived ease of use, and user acceptance of information technology. MIS Quarterly: Management Information Systems, 13(3), 319-339. https://doi.org/10.2307/249008

De Sousa, W. H., \& Yu, A. S. O. (2014). Decision Making Planning: The Meta-decision Approach. Engineering Management Research, 3(1), 41-55. https://doi.org/10.5539/emr.v3n1p41

Dellinger, A. B. (2005). Validity and the Review of the Literature. Research in the Schools, 12(2), 41-54.

Durdu, L., \& Dag, F. (2017). Pre-Service Teachers' TPACK Development and Conceptions through a TPACK-Based Course. Australian Journal of Teacher Education, 42(11), 150171. https://doi.org/10.14221/ajte.2017v42n11.10

Girod, M., \& Girod, G. (2006). EXPLORING THE EFFICACY OF THE. Journal of Teacher Education,57(5), 481-497. https://doi.org/10.1177/0022487106293742 
Goddard, R. D., Skrla, L., \& Salloum, S. J. (2017). The Role of Collective Efficacy in Closing Student Achievement Gaps: A Mixed Methods Study of School Leadership for Excellence and Equity. Journal of Education for Students Placed at Risk, 22(4), 220-236. https://doi.org/10.1080/10824669.2017.1348900

Hart, C. (1998). The literature review in research: Releasing the social science imagination. Doing a Literature Review, pp. 1-25. Retrieved from http://www.sjsu.edu/people/marco.meniketti/courses/ARM/s0/Literature-review-Hart.pdf

Hu, M., Arnesen, K. T., Barbour, M. K., Leary, H., Arnesen, K., Barbour, M. K., \& Leary, H. (2019). A Newcomer's Lens: A Look at K-12 Online and Blended Learning in the Journal of Online Learning Research. Journal of Online Learning Research, 5(2), 123-144. Retrieved from https://www.learntechlib.org/primary/p/195231/

Kaufman, D., \& Ireland, A. (2015). The potential of simulation for teacher assessment. The Complexity of Hiring, Supporting, and Retaining New Teachers Across Canada, 113. Retrieved from https://edu.uwo.ca/faculty_profiles/cpels/pollock_katina/documents/Hiring, Supporting and Retaining New Teachers Across Canada8.pdf\#page=125\%0Ahttp://summit.sfu.ca/system/files/iritems1/15853/Kaufman-Ireland.pdf

Koehler, M. J., \& Mishra, P. (2006). Technological Pedagogical Content Knowledge: A Framework for Teacher Knowledge PUNYA MISHRA. Teachers College Record, 108(6), 1017-1054. Retrieved from http://one2oneheights.pbworks.com/f/MISHRA_PUNYA.pdf

Limbong, E. (2017). Designing and Developing Supplemental Technology of PACI Model Materials through Blended Learning Methods. In Celt: A Journal of Culture, English Language Teaching \& Literature (Vol. 16). https://doi.org/10.24167/celt.v16i2.771

Malik, S., Rohendi, D., \& Widiaty, I. (2019). Technological Pedagogical Content Knowledge (TPACK) with Information and Communication Technology (ICT) Integration: A Literature Review. (January). https://doi.org/10.2991/ictvet-18.2019.114

Mccrae, R. R. (2010). The Place of the FFM in Personality Psychology. (1986), 57-64. https://doi.org/10.1080/10478401003648773

Oddone, K., Hughes, H., \& Lupton, M. (2019). Teachers as connected professionals: A model to support professional learning through personal learning networks. International Review of Research in Open and Distance Learning, 20(3), 102-120. https://doi.org/10.19173/irrodl.v20i4.4082

Özgen, K., \& Narl1, S. (2020). Intelligent data analysis of interactions and relationships among technological pedagogical content knowledge constructs via rough set analysis. Contemporary Educational Technology, 11(1), 77-98. https://doi.org/10.30935/cet.646769

Pulham, E., Graham, C. R., \& Short, C. R. (2018). Generic vs. Modality-Specific Competencies for K-12 Online and Blended Teaching. Journal of Online Learning Research, 4(1), 33-52. Retrieved from https://www.learntechlib.org/j/JOLR/v/4/n/1/ 
R.McCrae, P. T. C. (n.d.). Four ways five factors are basic-ScienceDirect.

Rankin, D. (2013). Predictors of success for high school students enrolled in online courses in a single district program. (May), 138. Retrieved from http://login.ezproxy1.lib.asu.edu/login?url=http://search.proquest.com/docview/136984972 5 ? accountid=4485\% 5Cnhttp://scholarscompass. vcu.edu/cgi/viewcontent .cgi $?$ article $=4061 \&$ context=etd

Reisenzein, R., \& Rudolph, U. (2008). The discovery of common-sense psychology. Social Psychology, 39(3), 125-133. https://doi.org/10.1027/1864-9335.39.3.125

Rice, J. K. (2003). ERIC - Teacher Quality_Understanding the Effectiveness of Teacher Attributes (p. 64). p. 64. https://doi.org/ISBN-1-932066-06-3

Rotter, J. B. (1981). The effects of reinforcement on preceding behavior depend in part on whether or not the reinforcement is perceived as contingent on the person's behavior, Acquisition and performance differ in chance versus skill situations. Stable individual differences. 1982. Retrieved from http://garfield.library.upenn.edu/classics1982/A1982MY10900001.pdf

Schmidt, D. A., Thompson, A. D., Koehler, M. J., \& Shin, T. S. (2014). CIE 2014 - 44th International Conference on Computers and Industrial Engineering and IMSS 2014 - 9th International Symposium on Intelligent Manufacturing and Service Systems, Joint International Symposium on "The Social Impacts of Developments in Information, Manufacturing and Service Systems" - Proceedings. CIE 2014 - 44th International Conference on Computers and Industrial Engineering and IMSS 2014 - 9th International Symposium on Intelligent Manufacturing and Service Systems, Joint International Symposium on "The Social Impacts of Developments in Information, Manufacturing and Service Systems” - Proceedings, 42(2), 2531p.

Theelen, H., van den Beemt, A., \& den Brok, P. (2019). Using 360-degree videos in teacher education to improve preservice teachers' professional interpersonal vision. Journal of Computer Assisted Learning, 35(5), 582-594. https://doi.org/10.1111/jcal.12361

Tschannen-Moran, M., Hoy, A. W., \& Hoy, W. K. (1998). American Educational Research Association Teacher Efficacy: Its Meaning and Measure. Source: Review of Educational Research, 68(2), 202-248.

Vita, G., \& Graham, C. R. (2017). Prepublication versions of manuscripts. https://doi.org/10.1504/IJTEL.2016.075961

Watson, G. (2006). Technology Professional Development: Long-Term Effects on Teacher SelfEfficacy. Journal of Technology and Teacher Education, 14(1), 151-166.

Zyda, M. (2005). From Visual to Virtual Reality to Games. IEEE Computer Society, (September), $25-32$. 
International Journal of Distance Education and E- Learning (IJDEEL) Volume V- Issue II (June, 2020) 